\title{
Geen water, geen volheid: Die dringende boodskap van die eksistensieël-teologiese betekenis van water
}



Water is no longer only a source of life, but at the same time entails the possibility of death. In this article the question is posed to the theological implications of the statement when God is proclaimed as creator and giver of life, and this very life is now threatened by various human activities (eg. industrialisation) or the lack of activities (eg. no sanitation) in which the availability of fresh water can no longer be taken for granted. Attention is specifically given to the availability and access to fresh water within the South African context from international, national and ecclesial reports. From theological considerations on the significance of water in a biblical context, a strong argument is presented for involvement with this crisis as specialised conversation partner.

\section{Inleiding}

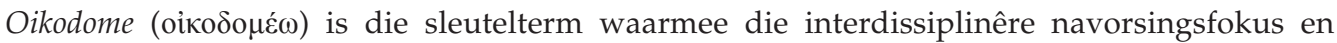
tema van die Fakulteit Teologie aan die Universiteit van Pretoria, Suid-Afrika, beskryf word. Hierdie sleutelterm dra die semantiese ladinge in wyduiteenlopende bybelse tekstuele kontekste ${ }^{1}$ van bou, genesing, restourasie, rekonsiliasie, vrede, versoening en die transendering van grense (vgl. Kok 2014). In kort word dit beskrywend aangewend as en saamgevat in die formulering van die 'volheid in God se huishouding'. In hierdie sistematies-teologiese bydrae tot die tema word die vraag gestel na die eksistensieël-teologiese betekenis van water in die oikodome. Opgesluit in die eenvoud van hierdie formulering van die betekenis van water, lê die diepsnydende implikasie dat water nie alleenlik 'n bron van lewe is nie, maar terselfdertyd ook van dood. Dit geld in ons alledaagse konkrete lewens as mense van vlees en bloed (en water), asook terselfdertyd in metaforiese beskrywinge van ons geloofsverhouding met God. Om die vraag na die eksistensieël-teologiese betekenis van water te beantwoord, word die sogenaamde vanselfsprekende belang van water vir en in die lewe eerstens bespreek en uitgelig ten einde aandag te skenk aan die dringende eietydse toespitsing op water wêreldwyd en in Suid-Afrika opnuut. Tweedens word die spirituele en teologiese betekenis (in metaforiese beskrywinge) van water bespreek, en dan laastens in die kort formulering van 'geen water, geen volheid' inhoudelike geïntegreer.

\section{Water is lewe en dood}

'Water is lewe' is die inleidende sin van sowel Waterwise se artikel oor Water sanitation in South Africa (2015) as Christiana Peppard ${ }^{2}$ (2012) se artikel oor vars water en Rooms-Katolieke sosiale denke. Beide brei onderskeidelik op hierdie basiese stelling uit. Waterwise (2015) voeg by: 'For millions of years life on earth has been dependent on water for survival'.

\section{Peppard (2012) voeg beskrywend by:}

In biblical, cosmological and geological sense, it is an early and vital matrix of creation. It is where prokaryotes took root, expanded into eukaryotic multicellular organisms, and shuffled onto land. Water remains a metabolic medium of the planet, a lifeblood for ecological systems and embodied creatures. (p. 325)

Geeneen sal die eerste stelling dat lewe op aarde reeds vir miljoene jare van water afhanklik is vir voortbestaan, bevraagteken nie. Hiervan is die tweede stelling net 'n herhaling en uitbreiding as kragtige beskrywing in die woorde van 'n 'vital matrix of creation'. Dit gaan egter nog verder

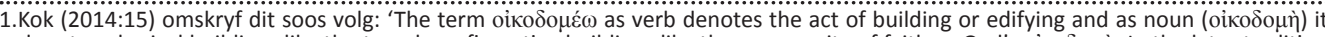
denotes physical buildings like the temple or figurative buildings like the community of faith as God's oikoסouǹ. In the later tradition of Paul and Peter for instance, we see that office bearers should be like stewards serving the community and building forth on and protecting the mysteries that have been received from the apostes. In the NT, the action of the "up to be directed towards those on the inside, i.e. it freems to have a the world? Do we find any evidence that this up-bulding also has a focus towards outsiders? The answer is yes! The early Christfollowers had a radical focus towards those on the inside ánd also towards the up-building and restoration of those outside the community of faith'.
}

2.Christiana Peppard is 'n sistematiese teoloog van Fordham Universiteit, New York, VSA. 
en benoem water as die lewensaar vir ekologiese sisteme en vir mense as beliggaamde wesens. Selfs nog belangriker in Peppard (2012) se kwalifiserende beskrywing van water as lewensaar, is die daaropvolgende konkrete omskrywing van sowel die konkrete as spirituele belang van water vir die mens:

Human relationships with water, especially fresh water, are universal foci of ritual, symbol and sacrament. This ubiquity is not surprising, for fresh water is a natural good that bears out life's possibilities, and is irreplaceable. In so many ways, fresh water is a sine qua non requirement for human life, and it is sui generis. For human beings and societies, for the fields we till and for the industrial processes we enact, the absence of clean fresh water augurs desiccation, decline, or death. (pp. 325-326)

Twee kwalifiseringe deur Peppard is hier van fundamentele belang: vars water as sine qua non ['n absolutenoodsaaklikheid] en as sui generis [uniek van aard]. In die hieropvolgende gedeelte word dit ook inhoudelik uitbouend beklemtoon.

Water is inderdaad lewe en die ontbreek of skaarste van water hou dood in. Maar nog 'n verdere dimensie kom vandag ter sprake waar die aanwesigheid van water - en dus nie net skaarste nie - ook dood kan inhou. Veral hierdie dimensie gaan sterk beklemtoon word. In die hieropvolgende paragraaf word kortliks aandag gegee aan die vraag oor wat presies water is (unieke aard), die wêreldwye voorkoms en belang daarvan (as absolute noodsaaklikheid), asook die watersituasie in Suid-Afrika.

\section{Water $^{3}$}

Water 'is vital for all known forms of life' (Wikipedia 2015:1) aangesien '[a]ll known forms of life depend on water' (Wikipedia 2015:7). Die Griekse filosoof, Thales van Miletus (600 vC), het water beskou as die basiese substansie van alles wat is - net soos wat alles deurtrek is met die gees van die gode! Vir hom was daar geen onderskeid tussen gees en materie nie. Sy jonger vakgenoot, Empedokles (490-430 vC), het water as een van die vier klassieke elemente van die universum beskou saam met vuur, lug en grond ('earth').

Water is 'n deurskynende vloeistof - meestal geproduseer as byproduk van die formasie van sterre - wat meer as $70 \%$ van die wêreldoppervlakte bedek en wat ons aantref in riviere, mere, oseane en reën. Dit kom ook voor as sneeu, mis, dou en wolke. Die aarde se watervolume is ongeveer $1338000000 \mathrm{~km}^{3}$. Slegs $2.5 \%$ van die aarde se water kom voor as vars water en daarvan is $98.8 \%$ in ys en grondwater. ${ }^{4}$ Dit is ook die belangrikste element van die vloeistof van lewende wesens ( $55 \%$ tot $78 \%$ van die menslike liggaam) en

3.Vir die data van die hieropvolgende beskrywinge is gebruik gemaak van Wikipedia (2015), Waterwise (2015), DWA (2012) en HDR (2006).

4.Vir meer omvattende data en beskrywinge, sien o.a. Jeffrey Rothfeder (2004) se Every drop for sale: Our desperate battle over water in a world about to run out Ook Fred Pearce (2007) se When the rivers run dry: what happens when our water runs out? So byvoorbeeld wys Pearce (2007:36) daarop dat slegs ses lande, naamlik Rusland, Kanada, China, Columbia, Indonesië en Brazilia meer as die helfte van Rusland, Kanada, China, Columbia, Indonesie en Brazilia meer as die helfte van
die wêreld se vars watervoorraad bevat. Asië het twee derdes van die wêreld se die wêreld se vars watervoorraad bevat. Asië h
bevolking, maar slegs een derde van die water! baie stowwe kan daarin oplos. Die chemiese samestelling van water is een suurstof en twee waterstof atome wat kovalent $t^{5}$ verbind is. ${ }^{6}$ Behalwe as vloeistof, kom water ook voor as vaste stof, naamlik ys, en as gas, naamlik stoom.

Alhoewel water geen kalorieë of voedingstowwe bevat nie, is veilige drinkwater noodsaaklik vir alle lewende wesens. Ten spyte van ernstige pogings wêreldwyd om veilige drinkwater te verseker vir meer mense, is daar vandag nog ongeveer een biljoen mense wat nie toegang het tot veilige drinkwater nie. Terselfdertyd het ongeveer 2.6 biljoen mense nie toegang tot voldoende sanitasie nie. Daar is wêreldwyd 'n direkte korrelasie tussen toegang tot veilige drinkwater en mense se ekonomiese status en vermoëns. ${ }^{7}$ Daarom stel die verslag van die Verenigde Nasies (Human Development Report 2006) dit so vreesaanjaend duidelik:

Access to water for life is a basic human need and a fundamental human right. Yet in our increasingly prosperous world, more than 1 billion people are denied the right to clean water and 2.6 billion people lack access to adequate sanitation. These headline numbers capture only one dimension of the problem. Every year some 1.8 million children die as a result of diarrhoea and other diseases caused by unclean water and poor sanitation. At the start of the 21st century unclean water is the world's second biggest killer of children [...] Meanwhile, the ill health associated with deficits in water and sanitation undermines productivity and economic growth, reinforcing the deep inequalities that characterize current patterns of globalization and trapping vulnerable households in cycles of poverty. (p. 5)

Water speel 'n beduidende rol op allerlei wyses in die wêreld-ekonomie. Ongeveer $70 \%$ van die vars water wat deur die mens verbruik word, word in die landbousektor verbruik. Daar word beweer dat teen 2025 meer as die helfte van die wêreld se bevolking waarskynlik watergebrek in die gesig gaan staar. Saam met die dreigende watergebrek soos in die voorafgande aanhaling uitgewys - kom die verskriklike toedrag van sake dat waterbesoedeling en gebrek aan sanitasie jaarliks amper twee miljoen kinders se dood veroorsaak. Op hierdie wyse word die huidige patrone en gevangenisse van armoede wêreldwyd voorgesit en versterk. In 2030 sal, in enkele ontwikkelende streke, die aanvraag na water die aanbod daarvan met $50 \%$ oorskry. Dit maak van water - sonder enige vrees vir teenspraak die belangrikste natuurlike element waarna die mens met

\footnotetext{
5.Die beskrywing van 'n kovalente verbinding verwys na die chemiese verbinding van atome waarin hulle elektronpare deel.

6.In die Wikipedia artikel oor water word op ' $n$ bondige wyse ' $n$ goeie samevatting gegee van die chemiese en fisiese eienskappe van water. Sien Wikipedia (2015).

7. Hierdie punt word veral sterk beklemtoon deur die United Nations Human Development Report met die titel Beyond scarcity: Power, povery and the global water crisis wanneer dit stel: 'Water for life in the household and water for livelihoods through production are two of the foundations for human development. Yet for a large section of humanity these foundations are not in place. The word crisis is sometimes overused in development. But when it place. The word crisis is sometimes overused in development. But when it comes to water, there is a growing recognition that the world faces a crisis that, left unchecked, will derail progress towards the Millennium Development Goals and hold back human development. For some, the global water crisis is about absolute shortages of physical supply. This Report rejects this view. It argues that the roots of the crisis in water can be traced to poverty, inequality and unequal power relationships, as well as flawed water management policies that exacerbate scarcity' (HDR 2006:5).
} 
groot verantwoordelikheid sal moet omsien $\ldots{ }^{8}$ Ook in Suid-Afrika. ${ }^{9}$

Suid-Afrika is 'n water-arm land, ${ }^{10}$ met amper die helfte van die gemiddelde reënval as die res van die wêreld (492 mm teenoor $985 \mathrm{~mm}$ ), en boonop is die verspreiding oor die land baie oneweredig. Wetenskaplikes (vgl. Waterwise 2015:8) beweer dat Suid-Afrika met aardverwarming meer ekstreme weertoestande sal ervaar: baie natter en baie droër seisoene. ${ }^{11}$ Ten spyte van die groot aantal damme in Suid-Afrika, sal die aanvraag die aanbod teen 2025 oorskry. Die aanbod van water word egter verder onder enorme druk geplaas deur die vraag na die kwaliteit van water (dit is, vars, drinkbare water) as gevolg van toename in besoedeling en die vernietiging van opvangsgebiede (bv. deur verstedeliking, ontbossing, opdam van riviere, vernietiging van vleilande - 'wetlands' industrieë, mynwese en landbou).

In die inleidende paragraaf van die Departement van Waterwese se verslag, The Annual National State of Water Resources Report October 2011 to September $2012^{12}$ (DWA 2012), word gestel:

South Africa is facing freshwater scarcity, which is exacerbated by its increasing demand, pollution, unsustainable use, and climate change. Water is critical for sustainable economic and social development as well as for maintaining healthy ecosystems. Over-abstraction and pollution continue to threaten the integrity of natural ecosystems, undermining ecosystem services. It is therefore crucial that water be conserved, managed and developed in an environmentally sound manner to achieve socio-economic development. A multidisciplinary

8.Met 'groot verantwoordelikheid omsien' het veral betrekking op die nuutste wêreldwye ontginning van die moontlikhede van hydraulic fracking. In dié verband stel Patenaude (2014), in sy gepubliseerde onderhoud met Peppard, haar standpun as volg: 'More recently, in the West, new technologies to extract natural gas have companies using millions of gallons of local water, blending it with proprietary chemicals, and injecting it all deep underground. This shatters shale deposits and releases natural gas. It also forces back to the surface much of the now-contaminated releases atural gas. I also 'hydraulic fracking' comes with great promise, but it does water. This process, called hydraulic fracking comes with great promise, but it does have people worried. The use and disposal of the contaminated water is largely unregulated. And because of the proprietary nature of the chemical additives, we don't really know what's remaining underground - and thus how it may impact the groundwater that other people drink - or what could be contaminating the billions of gallons collected and stored at the surface. Peppard evenhandedly lays out the promises and dangers of fracking. But she and many others - including local Catholic dioceses - are nonetheless wary about how both public and private organizations are going about their jobs. In Just Water Peppard notes that "it's reasonable to ask what's in our water before we drink it, shower with it, or give it to our children to quench their thirst"

9.In die Entebbe verklaring op 25 Mei 2007 van die Churches for water in Africa konferensie in Uganda word die volgende kort oproep ten opsigte van die watersituasie in Afrika gemaak (World Council of Churches 2007): 'We are deeply troubled by the aggravating impact of climate change which threatens to further alter the water patterns in Africa. Climate change is already causing unpredictable alter the water patterns in Africa. Climate change is already causing unpredictable
rainfall, prolonged droughts, devastating floods, desertification and drying up of rainfall, prolonged droughts, devastating floods, desertification and drying up of
water sources. The existence and future of millions of people is jeopardized. We water sources. The existence and future of millions of people is jeopardized. We
urge the industrialized countries to take their responsibility, and together with industrializing countries to start immediately to cut the emission of carbon dioxide, to put advanced alternative energy technology at the disposal of Africa and to assure funding for mitigation and adaptation measures in Africa, as well as in othe affected regions of the Global South'

10.In die verslag van Waterwise (2015:8) word Suid-Afrika as 'n 'water-stressed country' beskryf.

11.In die verslag van Department of Water Affairs (2012:1) word dit bevestig: 'There has been a noticeable increase in temperatures across the country in the past 40 years. During the summer months of $2011 / 2012$, temperatures greater than $26^{\circ} \mathrm{C}$ were observed in the Northern Cape, North West, Limpopo and northern parts of Kwa-Zulu Natal Provinces. The winter months saw temperatures soaring to below Kwa-Zulu Natal Provinces. The winter months saw temperatures soaring to below
$10^{\circ} \mathrm{C}$, resulting in some parts of the country experiencing cold conditions and snow $10^{\circ} \mathrm{C}$,
fall'.

12.Vir ' $n$ volledige oorsig met detail van die Suid-Afrikaanse situasie met betrekking tot water, sien die DWA (2012) se verslag. Hierdie artikel kan geensins aan die omvattende detail soos in hierdie verslag weergegee is, aandag geskenk word nie. and holistic approach should be adapted which will address the intricate nexus between water scarcity, water use and development. (n.p.)

Die verslag beklemtoon die dringende noodsaaklikheid om aan die dreigende probleem van waterskaarste aandag te skenk. Daar word spesifiek 'n multi-dissiplinêre en holistiese benaderingswyse tot die aanspreek van die probleem beklemtoon. Op 03 November 2014 het die volgende koerantberig van Emma Thelwell verskyn met die opskrif 'South Africa's looming water disaster' in aansluiting by die verslag van die DWA:

Gauteng's water was recently switched off because it was 'so close to the edge' - and that's just the beginning. The rest of the country is running on empty unless the government spends 100 times more to secure our water supply. In more than half of the country, South Africans are using more water than what's available. We are already using $98 \%$ of our available water supply, and $40 \%$ of our waste water treatment is in a 'critical state'. A staggering $37 \%$ of our clean, drinkable water is being lost through inefficient ways of using water such as leaking pipes, dripping taps - and that is what's being reported, the figure could be much higher. A recent government report, seen exclusively by News24, has found that a whopping R293bn needs to be spent over the next five years, otherwise we face a looming water crisis. This is 100 times more than the R2.9bn the department is expected to spend this year on water infrastructure management, Treasury estimates show. These worrying findings in the department of water and sanitation (DWS) report emerged just weeks after Water Minister Nomvula Mokonyane denied there was a crisis in the sector, blaming severe water shortages across Gauteng on a 'technical glitch' and the theft of electricity cables. (n.p.)

Thelwell (2014) wys in haar artikel daarop dat ons land alreeds 'at tipping point' is daarin dat aanvraag alreeds die wateraanbod oorskry in $60 \%$ van ons land se waterbestuursgebiede. Ons kan beslis nie hierdie dreigende krisis by geleentheid afmaak as ' $n$ 'tegniese glips' nie! Besoedeling en siektes wat deur water oorgedra word, is die belangrikste risiko's, met $40 \%$ van ons afvalwater wat behandel moet word aangesien dit in 'n 'critical state' is. Die groot probleem is ons infrastruktuur wat oud en onbetroubaar is, volgens Marius Claassen (Akwatiese ekoloog, Wetenskaplike en Nywerheidsnavorsingsraad). Met $8 \%$ van ons land wat $50 \%$ van ons water voorsien, sal ons intelligent en strategies na ons waterprobleem moet kyk. Veral omdat - aldus die Europeuse Unie se verslag oor water in Suid-Afrika - slegs 5\% van gevaarlike afval korrek hanteer word (Thelwell 2014). Dit vererger die skaarste van vars water baie. Die Suid-Afrikaanse Menseregtekommissie het kort voor die laaste verkiesing 'n ondersoek geloods na die situasie in ons land en bevind dat:

23 municipalities ( $9 \%$ of the total) were in a crisis state, with 'acute risk of disease outbreak'. A further 38\% were at high risk, with the 'potential to deteriorate into a state of crisis. (Thelwell 2014:n.p.)

Behalwe hierdie bestuurskrisis, is een van die ander belangrikste risikofaktore suurwater $(\mathrm{AMD}=$ acid mine 
drainage), afskomstig van ons mynbedrywighede (gouden steenkoolmyne). Die lys van bewese en moontlike mediese implikasies is skrikwekkend: van diarree, tot neuro-toksiologiese effekte (soos bv. geheueverlies, swak breinfunksie, Alzheimer, kanker) en velsiektes. Hierdie gevolge is waarskynlik die ergste in die myngemeenskappe waararmoede, vigs, voedseltekorteenkortlewensverwagtinge aan die orde van die dag is. Dit kan alles saamgevat word in die uiters dringende waarskuwing van die Europese Unie se verslag (Thelwell 2014): 'If social and economic issues are addressed separately from environmental issues, ecological and social collapse is certain'.

Ons kan dus nie anders as om hierdie toedrag van watersake met die grootste lewenserns op te neem vir die vermyding van dreigende ekologiese en sosiale ineenstortinge nie. Die wyse waarop dit ernstig opgeneem word, sal multi-dissiplinêr en holisties moet wees. Kortom, dit sal die fisiese en sosiale en ekonomiese dimensies van hierdie onvermydelike probleem in samehang of geïntegreerd moet aanspreek. Hierby word die spirituele (teologiese) dimensies ook in hierdie artikel bygevoeg. ${ }^{13}$ In hierdie samevoeging moet die dubbele doodsdreigement wat water inhou deur besoedeling en van siektes veral aandag geniet.

\section{Spirituele belang van water}

In die Suid-Afrikaanse konteks was die eerste voordrag wat ek gehoor het oor die dubbele gevaar wat water inhou nie net ten opsigte van skaarste nie, maar ook deur siektes soos cholera - die voordrag Water and spirit deur Steve De Gruchy, sistematiese teoloog van die School of Religion aan die Universiteit van Kwazulu-Natal. Hy lewer sy voordrag op 25 Junie 2009 by die jaarlikse kongres van die Dogmatologiese Werkgemeenskap in Stellenbosch. ${ }^{14}$ Skaars agt maande daarna, op 21 Februarie 2010, verdrink hy tragies. Op tragiesironiese wyse dra sy lewe die kragtige teologiese boodskap van water wat ook dood kan beteken.

In sy voordrag in Stellenbosch begin hy by die choleraepidemie wat Zimbabwe in 2008-2009 getref het. Hy stel voorop:

Cholera is a preventable disease, easily avoided and simply treated. Yet, not far from us, in a country that has been freed from colonial bondage, a tragedy was played out in the lives of those for whom liberation was intended. This narrative of tears brings together issues of political governance, public health, ecological collapse and the lives and livelihoods of the poor. It provides, in other words, an agenda for theological work; and because of the particular way in which this disease confronts us, theology in the time of cholera draws us to reflect again upon the relationship between spirit and water. (De Gruchy 2010:188)

13.Om maar een willekeurige voorbeeld te noem van die wyse waarop aan die land se waterprobleme reeds ernstige institusionele aandag geskenk word, kan gewys
word op die totstandkoming van die volgende drie leerstoele aan die Universiteit van Pretoria. Die 'Water Utilisation Division' wat in 1969 gestig is deur Rand Water en wat n leerstoel in Water Utilisation Engineering aan UP se African Water Issues Research Unit (AWIRU) befonds; ' $n$ tweede leerstoel is in 1998 ingestel toe ERWAT ingestem het om spesifiek aan afvalwater aandag te skenk; 'n derde leerstoel, naamlik die
Sedibeng Water Chair in Water Utilisation Engineering is in 2014 ingestel.

14.De Gruchy se voordrag is as artikel gepubliseer in die Ecumenical Review (2010) in uitgawe 62 wat aan hom opgedra is.
Sy uitnodiging as agenda vir teologiese nadenke aangrypend beskryf as 'n 'narrative of tears' - neem as uitgangspunt die interessante historiese agtergrond van die verhaal van cholera se oorsprong. Dit het by die Ganges riviervallei in Indië begin voordat dit deur Britse imperialistiese uitbreiding en handel epidemies oor die wêreld versprei het en die dood van miljoene mense veroorsaak het (vgl. De Gruchy 2010:188ev). Die belangrikste insig vanuit hierdie verhaal is die nuwe verstaan van die verspreiding van cholera - nie deur lug nie, maar water was dat water dood kon veroorsaak as draer, en nie net lewe bring soos altyd geglo is nie! Terselfdertyd was dit 'n verhaal wat kontekstueel afgespeel het te midde van grootskaalse verstedeliking en sosiaal-ekonomiese verskuiwinge. Die verhaal van cholera het 'n heel nuwe boodskap gebring (De Gruchy 2010:192): 'Cholera was a sign and symbol of ... social dislocation, and in the process water became something it was not. It became death'.

Oor water as fisiese oorsaak van dood moet daarom ernstig herbesin word vanuit die kragtige spirituele/teologiese boodskap dat water lewe inhou - maar ook dood. Ernstig herbesin vanuit die basiese geloofsbelydenis dat 'God, skepper van hemel en aarde' is en dus ook skepper van water. Ernstig herbesin omdat teologiese nadenke 'werklikheidsbetrokke' wil wees - en sodoende nie die werklikheid van hierdie implikasie kan ignoreer nie. Water hou ook dood in. Ernstig herbesin vanuit die fundamentele hermeneutiese insig dat ons ervaringe teorie-gelade is wat ons kenoordele en onderskeidingsvermoë deurtrek, en dus 'n onuitgesproke vervlegting van magsbelange, sosiaal-ekonomiese en politieke dimensies (bv. water en armoede) insluit. Ernstig herbesin vanuit interdissiplinêre en holistiese benaderingswyse.

Ten einde laasgenoemde inhoudelik aan te spreek, word eers kortliks aandag gegee aan die spirituele inhoud en belang van water. Daarna word 'n voorlopige integrering van hierdie insigte aangepak.

Water is in alle religieë van die wêreld van sentrale belang. Van besondere betekenis vir ons uiteensetting van die spirituele betekenis van water, is die dubbele betekenis daarvan, dit wil sê dat dit'n spirituele simbool van beide lewe en dood is. Water word religieus met reiniging en spirituele krag geïdentifiseer. In die vyf vernaamste wêreldreligieë (Judaïsme, Christendom, Islam, Buddhisme en Hindoeïsme) is van die mees vername betekenisinhoude ${ }^{15}$ van water:

- geen water, geen lewe nie

- water het reinigende en ook heilige krag

- water hou lewe én dood in

- gode en geestelike kragte woon dikwels in water

- water is 'n simbool vir skepping en bron van lewe

- terselfdertyd is dit 'n krag wat destruktiewe chaos teweeg kan bring.

15.Sien veral die interessante bespreking van De Gruchy (2010) waarin hy die Christelike geloofstradisie aanmoedig om die betekenis en rol wat water in ander geloofstradisies speel gerus maar ernstig op te neem. Hy verwys veral na Keltiese spiritualiteit wat die 5 de eeuse kerklike opdrag teengestaan het om natuurelemente (bv. bome, fonteine en klippe) nie te aanbid en plekke (soos bv. heilige putte) te vereer nie. 
In spesifieke verwysing na die Christendom, kan die volgende belangrike dimensies van water opsommerwys vanuit $\mathrm{Ou}$ Testamentiese tekste uitgelig word:

- Water is op die eerste skeppingsdag geskep met die gees van God wat oor die oppervlaktes van die water gesweef het (Gen 1:2; 6-8).

- Vanuit water kom lewe daaropvolgend voort (Gen 1:20).

- Water is lewe (Eks 15:23-35; 17:2-7; Ps 1:3; 22:2; 42:2; 46:5; 107:5,33).

- Water as reën (Gen 49:25; Rig 4:19).

- Water reinig of word as simbool in rituele gebruike of as offerhande (Lev 14:16; 1 Kron 11:18).

- Water vernietig (bv. as vloedwaters) of dreig (Gen 7; Ps 32:6; Jes 43:2).

- Water les fisiese dors van mense en diere (Gen 21:9; 24:10; Rig 4:19).

- Water word gebruik om kos mee te kook of om te was (Eks 12:9; 29:4).

- Water wat dood inhou - en selfs stink! (Eks 4:9; 7:17; 7:21).

- Water in uiteenlopende metaforiese beskrywinge: God soos stortreën (Hos 6:3), mens soos uitgestorte water (Ps 22:15), krag wat opdroog soos water in somerhitte (Ps 32:4), vrou soos put met water (Spr 5:15), mens se woorde of goeie oordele soos diep waters (Spr 18:4; Spr 20:5), om te dors na God (Ps 63:3).

- Water in wonderwerke (2 Kon 2:14).

In spesfieke verwysing na die Christendom, kan die volgende belangrike dimensies van water vanuit Nuwe Testamentiese tekste uitgelig word:

- Water les dors (Matt 10:42; Mark 9:41; Joh 4:7) en hou geestelike beloning in.

- Water as deel van ons liggaamsamestelling (Joh 19:34).

- Water as trane (Luk 7:44).

- Water as siekte (Luk 14) en medisyne (1 Tim 5:23).

- Water as oorsprong van hemel en aarde (2 Pet 3:5).

- Water en handewas of voetewas as handeling van onskuld en reiniging (Matt 27:14; Joh 13:5).

- Water in wondergenesinge (Joh 5:1-4) en wonderwerke (Joh 2:1-11).

- Water in reiniging en doop (Matt 3:1-6; 16; Mark 1:4-5; 10; Joh 1:26-33; Heb 10:22).

- Water in metaforiese beskrywinge: gebore uit water en Gees (Joh 3:5), Christus as lewende water en bron van ewige lewe (Joh 4:10-14; 7:38; Op 21:6; 22:17), die Een wat deur die water van sy doop en die bloed van sy dood na ons toe gekom het (1 Joh 3:6), deur doop saam met Hom in sy dood begrawe (Rom 6:4; vgl. Kol 2:12).

- Besmette water wat dood inhou (Op 8:11).

Met hierdie aanwysings van die spirituele betekenisse en kontekste waarin water besondere rol speel, word vervolgens geïntegreerd gevra na die betekenis wat dit kan inhou ten opsigte van die wêreldwye noodroep oor die aanvraag na vars water, die krisis van waterskaarste en die diepgaande dilemma van ekonomiese vermoëns en waterbeskikbaarheid.

\section{Geen water, geen volheid}

Die verantwoordelikheid vir vars water en sanitasie is nie alleenlik dié van regerings en munisipaliteite nie. Van hierdie krisis wat die ganse aarde bedreig en menslike voortbestaan op die spel plaas, moet teologiese nadenke van die 21ste eeu 'n gespesialiseerde gespreksgenoot van die betrokke rolspelers word. ${ }^{16}$ Dit sou my eerste passievolle pleidooi aan teologiese nadenke wees om met hierdie hermeneutiese ingesteldheid - dit is, as gespesialiseerde gespreksgenoot by die interdissiplinêre diskoers betrokke te raak. ${ }^{17}$ Tereg stel Ferris (2006):

In the coming years, as freshwater becomes increasingly polluted and scarce, water conservation will become a pressing ecological issue. Due to the essential nature of water, because it crosses political borders, transcends economic boundaries, and is such a fundamental cultural and religious symbol, all academic disciplines will contribute to the conversation, and among them, while not as intuitive as biology or economics, theology will have an important contribution to make. (n.p.)

Dan die allesbepalende vraag oor die besondere bydrae van teologie: Wat en waar sou 'n sinvolle en werklikheidsbetrokke teologiese invalshoek tot hierdie uiters dringende gesprek wees? Tereg merk De Gruchy (2009a) in hierdie verband op:

This link between economy and ecology is usually missing from our theological models. Liberation theologies focus on the Exodus tradition, and are concerned with economics and poverty. Creation theologies focus on the Genesis tradition, and are concerned with ecology and the environment. Isolated from the each other, these theologies miss the fact that 'we all live downstream'. We need to find a theological vision that integrates them. (n.p.)

16.Die keuse vir die betekenis van die term 'gespesialiseerde gespreksgenoot' kom van die direkteur van die Center of Theological Inquiry, Princeton (VSA), professor
Will Storrar, wat in 'n gespreksgeleentheid in Maart 2015 aan die Fakulteit Will Storrar, wat in ' $n$ gespreksgeleentheid in Maart 2015 aan die Fakulteit Teologie die volgende belangrike opmerking gemaak het oor interdissiplinêre navorsing. Die teoloog wat in gesprek tree met ander dissiplines (bv. biologie,
fisika, sielkunde, sosiologie, letterkunde, ens.) kan slegs hoop om in hierdie fisika, sielkunde, sosiologie, letterkunde, ens.) kan slegs hoop om in hierdie
gesprek die diskoers van die ander dissipline te verstaan en sinvol daarmee in gesprek te tree. Vandaar die term 'conversational specialist'. Die bedoeling is nooit om, byvoorbeeld, ' $n$ beter sielkundige (dalk nog erger: beterweterige sielkundige) te word as die sielkundige nie, maar slegs om by die diskoers van die ander dissipline(s) op 'n konstruktiewe wyse betrokke te raak. En dan belangrik: om 'n baie spesifieke teologiese bydrae tot die interdissiplinêre gesprek te maak vanuit die verstaan van die betrokke dissipline se bydrae. Dit is ook presies wat die verslag Appreciating assets: The contribution of religion to universal access in Africa van die African Religious Health Assets Programme (ARHAP 2006: 130-131) voor pleit wanneer dit selfondersoekend aan godsdiensleiers die vraag stel: 'How can we expect to make a real difference in the health and wellbeing of our communities, if we do not draw on the wisdom and experience of those of our communities, if we do not draw on the wisdom and experience of those van voorstelle in hierdie verslag so gepas beskrywe met die opskrif: 'Respectful dialogue - A way forward' (ARHAP 2006:130).

17.Op hierdie spesifieke wyse kan die bevinding en derde aanbeveling van die Suid-Afrikaanse etikus, Willem Fourie (2013:8), ter harte geneem word ten opsigte van sosiaal-etiese studies in Suid-Afrika wanneer hy skryf: 'It should be noted ... that few of the social ethical themes covered in the past decade seem to connect explicitly to the major economic and political changes experienced in South Africa. This can be ascribed to a number of factors, including the limited number of theologians in the field, the perception within and outside theology that theology does not have the legitimacy to play a role outside the church and ... the fact that the disjunction between thematic social ethical reflection and reflection from within the field - or taking cognisance of the field - is bound to lead to a rather haphazard collection of themes. On the basis of the aroument presented above the following conclusion seems appropriate of the argument presented above, the following conclusion seems appropriate: social ethics as a field clearly has an important role to play in South Africa as the country is experiencing significant processes of institutional and systemic changes. However, the disciplinary resources accumulated in the field nee to be re-appropriated, contextualised and developed further in order to address these realities in a relevant, reflective and grounded manner, in order
to eventually maximise the potential impact of contributions to this field of to eventually maximise the potential impact of contributions to this field of
study'. 
De Gruchy (2009a, 2009b) noem sy teologiese visie die Jordaan Perspektief $^{18}$ waarin verantwoordelikheid ten opsigte van die mens en aarde, en ook ekonomie en ekologie, gehandhaaf word. Sy visie gee konkrete inhoud aan die vroeëre Entebbe Verklaring (WCC 2007) in Uganda waarin gestel word:

As churches and faith based organisations we affirm water as the cradle and source of life, an expression of God's grace in perpetuity for the whole of creation. We are called to exercise responsible stewardship for this unique trust, and to preserve and share it for the benefit of humanity and all creation. Further we share the following convictions: that access to water is a fundamental human right, that the protection and control of water resources is a central public responsibility, and that water must not be treated as a commodity but as an essential social good for the present and future generations. We recognise water as a sacred gift of God. (n.p.)

Hoe verwoord ons dan interdissiplinêr en holisties hierdie 'sacred gift of God'? ${ }^{19}$ God as gewer van lewe het in die 21ste eeu vanuit hermeneuties-kontekstuele insigte by wyse van waterspreke 'n halwe waarheid geword. Sonder water is daardie lewe net nie meer moontlik nie. Verder, die fonteine wat volgens nuwe testamentiese perspektiewe (vgl. Jak 3:1112) nie uit dieselfde oog vars en brak water laat opborrel nie, het inderdaad by wyse van metaforiese spreke die sosiaalekonomiese en politieke fonteine van lewe (vars) en dood (brak) geword. Water - die uniekheid en besikbaarheid daarvan - het by uitnemendheid die antropologiese dimensies van menswaardigheid, sosiale geregtigheid en die integriteit van die skepping opnuut as menslike verantwoordelikheid na vore gebring. Dit is die teologiese verwoording en die positiewe aanvaarding van die sosiaal-etiese implikasie van Mattheus 25:35, waar gestel word: 'Ek was dors, en julle het My iets gegee om te drink'.

18.In sy Jordaan Perspektief, stel De Gruchy (2009a) op kreatiewe wyse: "Here I think a Jordan River perspective is helpful. It points to the People of Israel as they are
about to enter the Land of Promise. They are people of the Exodus, liberated from slavery. But now they are not just free. They are about to take on the responsibility slavery. But now they are not just free. They are about to take on the responsibility
of creating a society that honours both humanity and the earth. This is, after all, of creating a society that honours both humanity and the earth. This is, after all,
a land that will flow with milk and honey for generations to come. A Jordan River a land that will flow with milk and honey for generations to come. A Jordan River
perspective also reminds us of the strong links that the bible has to water. The perspective also reminds us of the strong links that the bible has to water. The
Jordan river flows from life (Sea of Gailiee) to death, (Dead Sea). It reminds us that human choices are taken between these two options, connecting economics and ecology, the Passover Festival (liberation) with the Festival of Weeks (creation) Such a perspective cannot be a legitimation of the modern state of Israel or othe imperial projects, for it is rooted in the Deuteronomic code of justice for the widow, the alien and the oppressed. Indeed the Jordan River perspective holds together economics and ecology, recognizing that "we all live downstream". It is a reminder that freedom is worth nothing for the poor if we cannot deal with sewage'. In Patenaude se onderhoud met Peppard oor haar boek, Just Water, maak sewage. In Patenaude se onderhoud met Peppard oor haar boek, Just Water, maak sy ook melding van die Jordaanrivier. Patenaude (2014) merk in hierdie verband op: 'Of special interest is a chapter about the demands on and the misuses of the ordan River. Peppard nicely weaves together the history of our Christian faith, the sacramental life of the Church, water-quality science, geo-political tensions, and management practices. The damage done to this sacred river is troubling in its own right. It also showcases more general water issues occurring across the globe - issues that naturally blend faith, reason, healthy profit motives, and a basic need for human life'.

19.Die volgende onlangse invloedryke voorbeelde van verwoording kan genoem word: Marjorie Keenan (2002) se From Stockholm to Johannesburg: An historical overview of the concern of the Holy See for the environment, 1972-2002; Denis Edwards (2006) se Ecology at the heart of faith: The change of hearts that leads to a new way of living on earth; Elizabeth Johnson (2007) se Quest for the living God: Mapping frontiers in the theology of God: Jame Schaeffer (2009) se Theological foundations for environmental ethics In di Suid-Afrikanse konteks het veral die foundations for environmental ethics. In die Suid-Afrikaanse konteks het veral die sistematiese teoloog, Ernst Conradie, aspekte hiervan aangespreek. Sien onder andere sy Hope for the earth - Vistas on a new century; An ecological Christian anthropology: At home on earth? (2005); Christianity and ecological theology: Resources for research (; Saving the Eark? The legacy of reformed views on 're-creation'. Veral ook die versamelwerk Christian faith and the earth: Current paths and emerging horizons in ecotheology van Sigurd Bergmann, Celia DeaneDrummond en Denis Edwards.
Lewe as gawe van God soos deur Christene bely en die noodsaaklikheid van water vir die realisering van juis hierdie lewe maak van die beskikbaarheid en toegang tot vars water 'n menslike reg. ${ }^{20}$ Water is beslis nie deel van ons lewens net om deur 'n paar bevoorregte lande, regerings of instansies misbruik of uitgebuit te word nie. Dit sou 'n dodelike belegging wees in toekomstige onvrede en konflik! Daarom sal grootskaalse kommodifisering van water teengestaan moet word vanuit Christelik, sosiaal-etiese oorweginge. Dit beteken eenvoudig dat diegene wat dit die minste kan bekostig (armes) mag nie uitgebuit word om ten duurste daarvoor te moet betaal nie. Vanuit 'n Christelike perspektief moet dit teengestaan word. Dit geld ook vir industrialisasie wat nie ongestoord toegelaat kan word om uit te brei sonder dat die omgewingsimplikasies noukeurig nagegaan word nie. Moontlike besoedeling van omgewingswater mag nie toegelaat word nie. Bo alles moet die menslike omgewing sowel as alle ander lewende wesens (flora en fauna) hulle regmatige ekosistemiese plek behou sonder grootskaalse versteuringe. Op hierdie wyse sal menslike voortbestaan nie ten koste van hulle leefomgewings bevorder word nie. Ook mag nie toegelaat word dat markmeganismes die waarde en verspreiding van water voorskryf nie. Anders kortweg gestel: die boek van die natuur - naas die boek van die skriftuur soos gestel in die belydenisskrifte - moet opnuut weer haar regmatige skeppingsplek en stem inneem. En die mens moet haar opdrag tot versorging van en omgee vir die skepping as verantwoordelikheid opnuut weer ernstig neem - holisties ernstig neem, dit wil sê, met verdiskontering terselfdertyd van sosiaal-ekonomiese, politieke en teologiese dimensies. Op hierdie wyse is - benewens toegang tot vars water as reg - ook voldoende sanitasie 'n onvermydelike vereiste van die handhawing van menswaardigheid en die spesifieke voorkoming van moontlike siektetoestande wat by gebrek aan voldoende sanitasie mag ontstaan.

\section{Slot}

\section{Om stroomaf te lewe}

Die erkenning in die woorde van Tara Lohan dat ons almal stroomaf lewe, sê dit treffend. ${ }^{21}$ Deur evolusie het alle lewe uit water ontstaan. Daar is net een stroom water. Net een! Van hierdie een stroom water is alle lewe afhanklik. In hierdie opsig lewe ons almal saam stroomaf. Alle lewe is stroomaf lewe. Water vloei deur ons menslike liggame. Dieselfde water vloei deur die diere, insekte en plante van die aarde, vloei deur ons riviere, verdamp die lug in, word wolke, kondenseer en voed deur reënwater alle lewe. Dieselfde water vloei ook deur ons netwerke van sanitasie. Daar is geen lewe buite hierdie watersiklus moontlik nie. Net so is, onder andere, teologiese nadenke 'n getuie en (uit)draer van die spirituele stroom van religiositeit waardeur die mensdom nie haar volle betekenis kan ontgin

$20.1 n$ die hieropvolgende gedeelte word in die uiteensetting in erkenning integrerend gebruik van insigte vanuit ' $n$ groot aantal bronne, waaronder dié van Christiana Peppard (2012, 2014), De Gruchy (2009a, 2009b), Ferris (2006), Pearce (2007) en Rothfeder (2004).

21. Hierdie mooi formulering is ' $n$ vertaling van die inleidende hoofstuk van die boek, Water consciousness, waarvan Tara Lohan (2008:8) die redakteur is. De Gruchy (2009a, 2009b) maak ook van hierdie mooi beeldspraak gebruik. 
of die waarde van menswees voor God kan ontsluit nie. Op hierdie wyse hou geen toegang tot vars water en gebrek aan sanitasie die implikasie in van 'geen volheid in God se goeie skepping' waarsonder nie een van die eksistensieëlteologiese inhoude van die oikodome - naamlik bou, genesing, restourasie, rekonsiliasie, vrede, versoening en die transendering van grense - verwesenlik kan word nie. Water is 'n noodsaaklike en unieke voorveronderstelling van elkeen van hierdie spirituele inhoude! Vanuit hierdie perspektief gesien, moet ons wat dus stroomaf lewe, bewustelik stroomop dink sodat die invloedryke markmeganismes van ekonomiese sisteme en politieke magsbelange blywend krities ontmasker sal word ter wille van die Een wie ons as die Gewer van alle lewe bely, en ter wille van die huishouding van God waarbinne die weerloses en magteloses nie toegang tot vars water ontneem mag word nie. Op hierdie metafories-kontekstuele wyse vloei die dors na God, toegang tot vars water, voldoende sanitasie, en geregtigheid alles konstruktief ineen - en waar dit 'n werklikheid gemaak word, is dit so verkwikkend soos lentereën wat die grond verkwik (vgl. Hos 6:3) en lewe laat voortspruit en onderhou.

\section{Erkenning \\ Mededingende belange}

Die outeur verklaar hiermee dat hy geen finansiële of persoonlike verbintenis het met enige party wat hom nadelig of voordelig kon beïnvloed het in die skryf van hierdie artikel nie.

\section{Literatuurverwysings}

African Religious Health Assets Programme (ARHAP), 2006, 'Appreciating assets: The contribution of religion to universal access in Africa', Report for the World Health Organisation, ARHAP, Kaapstad, besigtig 22 Maart 2015, by https://www.arhap. uct.ac.za/pub_WHO2006.php

Bergmann, S., Deane-Drummond, C., Edwards, D., 2014, Christian faith and the earth Current paths and emerging horizons in ecotheology, T\&T Clark, London.

Conradie, E. [2000] 2005, Hope for the earth - Vistas on a new century, University of the Western Cape/ Wipf \& Stock, Bellville/Eugene.

Conradie, E., 2005, An ecological Christian anthropology: At home on earth?, Ashgate, Aldershot.

Conradie, E., 2006, Christianity and ecological theology: Resources for research, SUN Press, Stellenbosch.
Conradie, E., 2013, Saving the Earth? The legacy of reformed views on 're-creation', LIT Verlag, Münster.

De Gruchy, S., 2009a, 'Dealing with our own sewage: A Jordan River perspective', in Ecumenical Water Network, besigtig 22 Maart 2015, by http://water.oikoumene. org/en/whatwedo/seven-weeks-for-water/past/2009-water-and-justice/dealingwith-our-own-sewage-a-jordan-river-perspective

De Gruchy, S., 2009b, 'Dealing with our own sewage: Spirituality and ethics in a sustainable agenda', Journal of Theology in South Africa 134, 53-65.

De Gruchy, S., 2010, 'Water and Spirit: Theology in the time of cholera', The Ecumenical Review 62(2), 188-201. http://dx.doi.org/10.1111/j.1758-6623.2010.00057.x

Department of Water Affairs (DWA), 2012, National State of Water Resources Report 2011/12, besigtig 22 Maart 2015, by https://www.dwaf.gov.za/Groundwater/ documents/2011-12

Edwards, D., 2006, Ecology at the heart of faith: The change of hearts that leads to a new way of living on earth, Orbis, Maryknoll.

Ferris, M.H., 2006, 'When the well runs dry: An exploration of water conservation and blue theology', Reconstruction: Studies in Contemporary Culture 6(3), besigtig 22 Maart 2015, by http://reconstruction.eserver.org/Issues/063/ferris. shtml

Fourie, W., 2013, 'Social ethics in South Africa: Initiating a dialogue between its relevance and current status', HTS Teologiese Studies/Theological Studies 69(1), Art. \#1978. http://dx.doi.org/10.4102/hts.v69i1.1978

Human Development Report (HDR), 2006, Beyond scarcity: Power, poverty and the global water crisis, besigtig 21 Maart 2015, by http://www.undp.org/content/ dam/undp/library/corporate/HDR/2006-Beyondscarcity-Power-poverty-and-theglobal-water-crisis.pdf

Johnson, E., Quest for the living God: Mapping frontiers in the theology of God, Continuum, New York.

Kok, K., 2014, 'The radicality of early Christian oikodome: A theology that edifies insiders ánd outsiders', ongepubliseerde voordrag by Oikodome symposium, Universiteit van Pretoria, 27-28 Oktober.

Keenan, M., 2002, From Stockholm to Johannesburg: An historical overview of the concern of the Holy See for the environment, Pontifical Council for Justice and Peace, Vatican City.

Patenaude, W.L., 2014, 'Justice and fresh water. Interview with $\mathrm{Dr}$ Peppard', in The Catholic World Report, besigtig 23 Maart 2015, by http://www. catholicworldreport.com/Item/3018/justice_and_fresh_water.aspx

Pearce, F., 2007, When the rivers run dry: What happens when our water runs out? Transworld, Londen.

Peppard, C.Z., 2012, 'Fresh water and Catholic social teaching: A vital nexus', Journal of Catholic Social Thought 9(2), 325-351. http://dx.doi.org/10.5840/ jcathsoc20129223

Peppard, C.Z., 2014, Just water: Theology, ethics, and the global water crisis, Orbis Books, Maryknoll.

Rothfeder, J., 2004, Every drop for sale: Our desperate battle over water in a world about to run out, Penguin, New York.

Schaeffer, J., 2009, Theological foundations for environmental ethics, Georgetown University Press, Washington, D.C.

Thelwell, E., 2014, 'South Africa's looming water disaster', News24, 03 November, besigtig 21 Maart 2015, by http://www.arc.agric.za/Agricultural

Waterwise, 2015, Water situation in South Africa (Rand Water), besoek op 20 Maart 2015, by http://www.waterwise.co.za/site/water/environment/situation.html

Wikipedia, 2015, 'Water', besigtig 20 Maart 2015, by https://en.wikipedia.org/wiki/ Water

World Council of Churches (WCC), 2007, 'Entebbe Statement', Churches for water in Africa konferensie, Entebbe, Uganda, Mei 21-25, 2007, besigtig 20 Maart 2015, by http://www.oikoumene.org/en/folder/ documents-pdf/EWN_Entebbe_ Statement.pdf 